\title{
ANALISIS FENOMENOLOGI TENTANG PENGALAMAN PERAWAT DALAM MEMBERIKAN ASUHAN KEPERAWATAN PADA PASIEN DENGAN AVIAN INFLUENZA
}

\author{
Sri Yona*, Astuti Yuni Nursasi***
}

\begin{abstract}
Abstrak
Perawat adalah tenaga kesehatan yang paling sering kontak dengan pasien. Ketakutan akan tertular penyakit dalam merawat pasien dengan penyakit yang mudah menular, dapat melahirkan sikap dan perilaku perawat yang tidak profesional dalam memberikan asuhan keperawatan kepada pasien. Penelitian fenomenologi ini bertujuan mengidentifikasi pengalaman perawat selama merawat pasien dengan Avian Influenza. Data kualitatif yang diperoleh melalui wawancara mendalam pada tujuh perawat di sebuah rumah sakit di Jakarta. Hasil penelitian menemukan empat tema utama yaitu pengetahuan tentang AI yang minimal, profesionalisme yang tinggi, perasaan merawat pasien, serta upaya mencegah penularan. Hasil penelitian ini menyimpulkan bahwa perlunya pelatihan mengenai Avian Influenza dengan menggunakan pendekatan keperawatan.
\end{abstract}

Kata kunci: avian influenza, merawat, pasien, perawat

\begin{abstract}
Nurse is the only health team member in the hospital who always contact intensively with the patient. Fear of getting infection from patient can create negative perception and attitude which will influence the way nurse perform nursing care to the patient. This is important to assess what nurse perception in caring for infectious patiens, such as Avian Influenza (AI) patients. A Phenomenology study was carried out to identify the experience of nurses in taking care patient with Avian Influenza. The purpose of the study was to identify the experience of nurses in taking care patients with Avian Influenza. The participants were seven nurses who work at a hospital in Jakarta. Data was collected by the in-depth interview. The major themes revealed in this study were: inadequate knowledge about Avian Influeza, highly prefessional nurses, feeling when caring for patient, way in preventing AI transmission. In conclusion, there is a need to conduct additional training about Avian Influenza in the context of nursing care approach.
\end{abstract}

Key words: avian influenza, caring, nurses, patients

\section{LATAR BELAKANG}

Jumlah penderita Avian Influenza (AI) saat ini mengalami peningkatan yang cukup tajam. Jumlah penderita AI di dunia pada tahun 2003 hanya empat orang dan menjadi 116 di tahun 2006. Total penderita AI di dunia hingga bulan Februari 2007 adalah 272 dan 166 meninggal dunia. Vietnam, Indonesia, dan Cina merupakan tiga negara yang memiliki jumlah kasus AI terbesar di dunia (WHO, 2007).

Penyakit Avian Influenza ini menimbulkan ketakutan secara global sejak diketahui penularan virusnya dari hewan ke manusia. Avian Influenza pertama kali ditemukan di Indonesia pada bulan Juni 2005 dan telah menginfeksi manusia sebanyak 19 orang dan 12 diantaranya meninggal dunia (WHO, 2007). Total kasus AI di Indonesia hingga bulan Februari 2007 adalah 81 orang dan 77,8\% berakhir dengan kematian (WHO, 2007).

Wabah virus AI sampai saat ini diduga ditular melalui kontak langsung para korban dengan hewan unggas peliharaan mereka (Thomas \& Noppeenberg, 2007). Jumlah penderita AI yang semakin meningkat tiap tahun dengan tingkat mortalitas yang tinggi dan menyebar pada beberapa negara, maka Avian Influenza termasuk penyakit yang bersifat pandemik. 
Tindakan utama yang dilakukan dalam penatalaksanan Avian Influenza saat ini adalah memberikan antivirus dan vaksin (WHO, 2007). Akan tetapi, hingga kini belum terdapat bukti yang nyata akan keefektifan penggunaan vaksin dan antivirus dalam mengurangi angka mortalitas kematian pasien (Goodman et al., 2006).

Perawat sebagai tenaga kesehatan yang paling sering kontak dengan pasien memiliki risiko tertular virus AI. Perawat adalah salah satu tenaga kesehatan dengan jumlah besar dalam pusat pelayanan kesehatan, terlibat secara langsung dan kontak dengan pasien selama 24 jam. Walaupun hingga saat ini belum terdapat bukti adanya penularan virus ke perawat di Indonesia, tetapi risiko tertular virus tetap tinggi (WHO, 2007). Adanya risiko tertular penyakit tersebut dapat menimbulkan ketakutan dan keengganan pada perawat untuk kontak dan merawat pasien AI. Hal ini dapat memengaruhi penampilan perawat dalam merawat pasien, bahkan dapat menjadi alasan bagi perawat untuk meninggalkan pekerjaanya (Shiao et al., 2007).

Persiapan perawat secara dini dalam bentuk meningkatkan pengetahuan dan keterampilan merawat pasien AI akan berdampak positif dalam mengatasi ketakutan serta permasalahan yang sering timbul dalam merawat pasien AI, dampak akhirnya akan meningkatkan mutu pelayanan keperawatan secara optimal.

\section{METODOLOGI}

Penelitian ini menggunakan desain penelitian fenomenologi, yang bertujuan untuk mengidentifikasi dan mengeksplorasi pengalaman perawat yang merawat pasien Avian Influenza. Tujuh responden yang terlibat pada penelitian ini.

Tujuh responden ini adalah perawat yang merawat pasien AI di sebuah RS di Jakarta, masa kerja minimal satu tahun, mampu berbahasa Indonesia dengan baik, serta mau berpartisipasi dalam penelitian ini.
Wawancara mendalam dilakukan selama 6090 menit. Analisis data dilakukan dengan cara mendengarkan kembali rekaman wawancara. Setiap pernyataan partisipan, dikelompokkan, disusun, dianalisis serta diinterpretasikan oleh peneliti (Polit \& Hunger, 2003). Pengumpulan data dilakukan selama 12 minggu sepanjang bulan September-November 2007.

\section{HASIL PENELITIAN}

Profil demografik responden meliputi pendidikan dengan rentang D3-S1 keperawatan, mayoritas berjenis kelamin wanita (5 wanita berbanding 2 pria) dengan rentang usia 31-52 tahun. Lama bekerja responden sebagai perawat di RS tersebut mempunyai rentang 2,5-24 tahun. Perincian selengkapnya profil demografik responden dapat dilihat pada tabel 1 .

Tabel 1. Profil demografik responden

\begin{tabular}{llrll}
\hline $\begin{array}{l}\text { No. } \\
\text { responden }\end{array}$ & $\begin{array}{c}\text { Jenis } \\
\text { kelamin }\end{array}$ & Usia & $\begin{array}{l}\text { Tingkat } \\
\text { pendidikan }\end{array}$ & $\begin{array}{l}\text { Lama } \\
\text { bekerja }\end{array}$ \\
\hline R1 & laki-laki & 33 tahun & Sarjana & 9 tahun \\
R2 & perempuan & . 37 tahun & Diploma & 19 tahun \\
R3 & perempuan & 37 tahun & Diploma & 12 tahun \\
R4 & perempuan & 48 tahun & Diploma & 24 tahun \\
R5 & perempuan & 36 tahun & SPK & 4 tahun \\
R6 & perempuan & 31 tahun & Sarjana & 3 tahun \\
R7 & laki-laki & 31 tahun & Diploma & 2 tahun \\
\hline
\end{tabular}

Pengetahuan responden tentang perawatan pasien AI sangat beragam. Berikut ini diuraikan pengalaman perawat dalam merawat pasien AI.

\section{Pengetahuan tentang Avian Influenza}

\subsection{Pengetahuan tentang sumber penularan Avian Influenza}

Pengetahuan responden mengenai sumber penyakit AI bervariasi. Sebagian berpendapat penularan AI belum jelas dan misterius. Sebagian lain berpendapat penularan AI melalui unggas serta tidak menular dari manusia ke manusia.

“...penularannya kan belum jelas” (R3) 
“...masih misterius ..." (R7)

“...flu burung diketahui penyebabnya dari unggas, menular melalui unggas" (R2)

“...didapat dari unggas atau ayam yang mati” $(\mathrm{R})$

“...nggak menular lah dari manusia ke manusia” (R4)

Ada juga responden yang berpendapat bahwa Avian Influenza adalah penyakit yang sangat menular, seperti pneumonia yang disertai dengan gejala panas tinggi.

“...biasanya pasien pneumonia, infeksi paru” (R4)

"Penyakit yang sangat menular ... demam lebih dari 38 derajat" (R2)

“Yah,...pneumonia biasa...yah, kadang gejala kayak flu, sakit tenggorok, demam, kadang muntah” (R3)

Hanya dua responden yang memiliki tingkat pendidikan sarjana yang mengatakan bahwa flu burung berasal dari virus Avian Influenza (H5).

"Flu burung itu suatu penyakit yang disebabkan oleh virus, yah, virus human Influenza yang sifatnya mematikan” (R1)

\subsection{Pengetahuan tentang cara perawatan pasien Avian Influenza}

Pengetahuan responden akan perawatan juga bervariasi. Sebagian berpendapat cukup menempatkan pasien di ruang isolasi dan diperiksa darahnya. Sebagian lainnya, pada tahap awal, tidak mengetahui secara pasti cara perawatan pasien Avian Influenza. Responden tersebut mencari informasi sendiri dengan membaca buku atau memperolehnya dari pengalaman pribadi. Sebagian responden mendapat pengetahuan dari pelatihan singkat.

“... saya belum tahu apa-apa tentang flu burung, saya meraba-raba..." (R1)

“...baca-baca buku...”(R2)

“...hanya pendidikan sekilas tentang APD (alat pelindung diri)..."
Responden menemukan beberapa kendala pada waktu merawat pasien antara lain kaca mata yang berembun, pakaian APD yang tebal, panas, dan sesak, serta enggan untuk masuk ke ruang ICU karena malas mandi setelah keluar dari ruang AI.

“...kacamata google berembun, jadi nggak kelihatan” (R4)

“Pakaian APD terasa sesak, panas” (R6, R2)

“...malas mandi setelah dari ruang AI..."

\section{Loyalitas merawat pasien}

Mayoritas responden memiliki rasa tanggung jawab yang besar dalam merawat pasien Avian Influenza. Dua motivasi utama teridentifikasi sebagai motivasi yang mendasari responden tetap merawat pasien yaitu motivasi internal yang berasal dari diri responden dan motivasi eksternal terutama berupa dukungan dari lingkungan.

\subsection{Motivasi Internal}

Mayoritas responden tetap melaksananakan kewajiban merawat pasien Avian Influenza karena sudah merupakan kewajiban bagi setiap perawat.

“...yah, tugas kita sebagai perawat, mau diapain lagi. Dengan ikhlas aja.” (R2)

“...namanya juga merawat pasien yang begitu, sama juga kalau kita merawat pasien dengan HIV, sama juga kan...”(R2)

“...tugas saya sebagai perawat, panggilan jiwa.” (R3)

\subsection{Motivasi eksternal}

Motivasi eksternal yang mendasari responden merawat pasien Avian Influenza adalah adanya uang jaga yang lebih tinggi dibandingkan dinas di tempat lain.Adanya tambahan makanan serta vitamin bagi perawat juga merupakan motivasi eksternal bagi responden untuk tetap merawat pasien di ruang Avian Influenza.

“...sudah ada uang transport...satu kali jaga $R p$ 50.000,-” (R1) 
“... kita juga dapat makanan tambahan, ekstra gitu...sudah cukuplah menambah stamina...makanan, telur, vitamin" (R4)

“...karena kebetulan disini suplai gizi,TKTP lah, disini tersedia untuk jaga ...cukuplah.” (R6)

Dukungan yang adekuat dari keluarga (pasangan, saudara) juga merupakan faktor lain yang memotivasi perawat untuk tetap merawat pasien.

“...paling warning aja dari suami...” (R6)

“...saya ceritain perlindungan (diri), jadi nggak takut” (R4)

“...keluarga saya kasih penjelasan, jadi nggak lah... (nggak takut)” (R7)

Alat pelindung diri yang selalu tersedia di RS membantu meningkatkan kepercayaan diri perawat dalam merawat pasien Avian Influenza. Ruangan khusus untuk pasien Avian Influenza yang dilengkapi dengan pendingin ruangan juga membuat perawat merasa lebih nyaman dan tidak gerah di ruang isolasi.

“...pakai APD lengkap, soalnya alatnya komplit disini...” (R4)

“...diawal, pakai APD gerah...sekarang jadi ruangan tuh ber AC...lebih nyaman” (R6).

\section{Perasaan merawat pasien Avian Influenza}

\subsection{Perasaan awal merawat pasien}

Mayoritas responden mengungkapkan kecemasannya akan tertular penyakit di awal kontak dengan pasien Avian Influenza.

“...awalnya cemas ...” (R2)

“...cuma yah...deg-degan, ada lah..tetap ada perasaan was-was.” (R2, R3, R4)

“Pertama, saya takut juga.” (R5)

"Saya takut juga, takut tertular penyakit" (R2)

\subsection{Pengalaman setelah merawat pasien minimal satu tahun}

Perasaan empati yang mendalam timbul karena pasien yang dirawat berakhir akhirnya meninggal.
Ada pula perawat yang merasakan stres yang terbawa sampai pulang ke rumah.Ada juga yang merasa sedih dengan teman yang sakit/ terluka selama dinas di ruang khusus perawatan pasien AI.

“...empati pada pasien yang meninggal.” (R1)

“Stres ... dibawa pulang ... .” (R1, R4, R6)

"Sedih kalau ada teman yang sakit." (R3)

“Kalau positif, cemasnya nambah.” (R1, R2, R3)

\subsection{Pengalaman luar biasa}

Beberapa responden mengalami pengalaman yang luar biasa selama merawat pasien, misalnya senang bila pasien yang telah dinyatakan positif AI dapat sembuh kembali.

“Pasien positif, bisa sembuh.” (R1, R3)

Ada juga yang mengungkapkan pengalaman yang tidak nyaman selama merawat pasien, yaitu adanya cedera setelah membantu dokter di ruang perawatan AI.

"Tergores jarum pasien setelah membantu dokter" (R2)

Pengalaman tergores jarum tersebut sempat membuat salah satu responden panik dan cemas yang berkepanjangan, karena takut tertular penyakit Avian Influenza.

“...iya, sempat kepikiran....aku stres, sampai nangis segala...benar-benar takut tertular....karena virusnya berjangkit kan kita nggak tahu.” (R2)

\section{Upaya mengurangi risiko tertular}

Mayoritas responden tetap menganggap pasien adalah sumber infeksi sehingga mereka tetap menerapkan kewaspadaan selama kontak dengan pasien. Ada yang meminimalkan kontak langsung dengan pasien, ada juga yang merasa aman terlindung setelah memakai pakaian APD lengkap.

“...pokoknya kontak jangan sesering mungkin...jadi diminimalkan, karena lelah..."(R6)

jadi kalo kita udah lengkap (APD), nggak masalah. Lah, handscoon udah dua, nggak ada masalah. (R4) 
...yang penting kita pakai APD lengkap, yah, nggak takut tertularlah, kita juga mesti berhatihati. (R2)

...saya ada rasa takut juga, cuma kalo pake APD lengkap, merawat dengan tulus dan ikhlas, Yang Di Atas juga tahu. (R3)

...mungkin diawal-awal iya (takut), tapi sekarang udah mengetahui proses penularannya, yang penting APD lengkap ...(R6)

...jadi kami udah dua tahun yang lalu, jadi udah bisa beradaptasi merawat pasien dengan flu burung. (R1)

\section{PEMBAHASAN}

\section{Pengetahuan responden tentang Avian Influenza}

Pengetahuan tentang Avian Influenza dan cara perawatan pasien Avian Influenza yang rendah ditemukan pada mayoritas responden. Hanya ditemukan dua responden yang dapat menjelaskan tentang penyakit Avian Influenza. Hal ini terkait dengan tingkat pendidikan formal responden yang cukup tinggi (sarjana). Hasil yang ditemukan ini sesuai dengan penelitian yang telah dilakukan oleh Tzeng (2001) bahwa tingkat pengetahuan dan pendidikan seseorang dapat mempengaruhi kemampuan seseorang dalam berperilaku.

\section{Loyalitas merawat pasien}

Hampir semua responden menyatakan kesediaannya merawat pasien Avian Influenza. Hal ini didasari oleh motivasi internal dari diri responden akan tanggung jawab dan panggilan jiwa merawat pasien. Hasil penelitian ini juga sesuai dengan Tzeng (2006) yang menemukan adanya kesediaan perawat untuk tetap merawat pasiennya, walaupun penyakit Avian Influenza akan mewabah nantinya.

Faktor eksternal yang mendukung responden tetap melaksanakan kewajiban mereka sebagai perawat adalah dukungan dari instansi tempat mereka bekerja, seperti adanya reward berupa uang transportasi, tambahan makanan serta vitamin yang cukup menunjang stamina perawat selama mereka merawat pasien.

Keinginan untuk meninggalkan pekerjaan tidak tercetus dari responden meskipun mereka memiliki risiko tertular penyakit. Hal ini berbeda dengan hasil penelitian yang Tzeng (2003) di Taiwan yang menemukan adanya keinginan perawat untuk meninggalkan pekerjaannya bila ditugaskan merawat pasien penyakit infeksius seperti Severe Acute Respiratory Syndrome/SARS.

\section{Pengalaman merawat pasien}

Stres yang dialami seseorang selama menjalankan pekerjaan merupakan tanda ditemukannya situasi yang sulit di lingkungan kerja. Penelitian ini menemukan adanya stres tersebut yang dialami oleh sebagian besar responden. Adanya stres ini menunjukkan bahwa perawat yang bertugas merawat pasien Avian Influenza memang berhadapan dengan situasi sulit. Namun, perawat tetap peduli dengan pasien dan tetap memberikan yang terbaik bagi pasien yang sedang dirawat, membuktikan bahwa aspek caring perawat Indonesia adalah tinggi. Temuan ini sesuai dengan hasil penelitian yang dilakukan oleh Cronquest (2004) yang mencatat tingginya sikap caring perawat yang dinas di ruang $I C U$.

\section{Upaya mengurangi risiko tertular penyakit}

Adanya risiko tertular penyakit membuat semua responden melakukan beberapa upaya untuk meminimalkan risiko tertular penyakit tersebut. Mayoritas responden memakai alat pelindung diri selengkap mungkin. Hal ini sesuai dengan rekomendasi Center for Diseases Control/CDC (2008) tentang alat pelindung diri bagi tenaga kesehatan, yaitu alat pelindung mata, sarung tangan, dan gaun. Alat pelindung diri yang dikenakan Di instansi tempat penelitian ini meliputi sarung tangan, kacamata pelindung, dan pakaian tiga lapis sehingga sesuai dengan rekomendasi CDC.

Upaya lain yang dilakukan adalah meminimalkan kontak perawat dengan pasien. 
Jurnal Keperawatan Indonesia, Volume 12, No. 1, Maret 2008; hal 1-6

Upaya ini sekalipun maksudnya baik, tetapi jika dikaitkan dengan profesi perawat ditemukan keadaan yang kontradiktif karena secara moral perawat wajib menjaga pasien seoptimal mungkin. Metode jaga bergantian dapat diterapkan di ruang AI untuk mengatasi hal ini. Metode ini dinilai cukup efektif karena perawatan optimal tetap dapat diberikan.

\section{KESIMPULAN}

Penelitian ini menemukan bahwa sekalipun sebagian besar responden pernah mendengar informasi tentang Avian Influenza, dari media informasi seperti koran dan televisi, tetapi pengetahuan mereka tentang penyakit AI serta cara merawat pasien AI sangat minimal. Minimnya tingkat pengetahuan perawat tersebut akan berdampak negatif pada asuhan keperawatan yang diberikan kepada pasien. Untuk mengatasinya disarankan perlu diselenggarakan pelatihan bagi petugas kesehatan tentang penyakit serta cara merawat pasien Avian Influenza sehingga perawat memiliki dasar yang cukup dalam memberikan asuhan keperawatan yang optimal bagi pasien.

Hasil lain yang diperoleh dari penelitian adalah tingginya profesionalisme perawat dalam merawat pasien dengan Avian Influenza. Hal ini terlihat dari tetap adanya keinginan untuk merawat pasien Avian Influenza, walaupun ada risiko tertular penyakit. Hasil lainnya setelah diperolehnya informasi tentang berbagai upaya pencegahan penularan penyakit, yakni menggunakan Alat Pelindung Diri lengkap sesuai dengan rekomendasi CDC (AA).
* StafAkademik Keperawatan MedikalBedah FIK UI

** Staf Akademik Keperawatan Komunitas FIK UI

\section{KEPUSTAKAAN}

Cronquest, A. (2004). Caring for moral obligation and work responsibility in intensive care nursing. Sage Publication.

Goddmanc, Mukhee, D., Faukner, E. (2007). How Effective would antiviral vaccine and antiviral drugs prevention and treatment strategies for reducing the impact of the next influenza pandemic.

Shiao, J., Koh, D., Lim, M., Guo, Y. ( 2007). Factors Predicting nurses' considering of leaving their jobs during the SARS outbreak. Nursing Ethics, $14,1$.

Tzeng, H-M.(2003). Nurse's professional care obligation and their attitude toward SARS infection control measures in Taiwan during and after the 2003 epidemic. Nursing Ethics, $11,277-89$.

Tzeng, H-M., Yin, C-Y. ( 2006). Nurses/ fears and professional obligations concerning possible human to human avian flu. Nursing Ethics, 13, 5.

Thomas, J. \& Noppeenberg, J. (2007). Avian influenza: A review. American Journal HeathSystem Pharmacy, 64, 149-65.

WHO. (2007). Fact Sheet: Avian Influenza. http:// www.who.intl/medicarecentre/factsheets/ avian_influenza/en/index.html, diperoleh 19 Februari 2007. 